\title{
The Cost of Safety During a Pandemic
}

\author{
Rachel M. B. Greiner ${ }^{1}$
}

Accepted: 31 December 2020 / Published online: 6 March 2021

(c) The Author(s), under exclusive licence to Springer Nature B.V. part of Springer Nature 2021

\begin{abstract}
A first-person account of some victims of the virus, the author puts faces and circumstances to the tragedy of the Covid-19 pandemic. Told from a chaplain's point of view, these narratives will take the reader beyond the numbers and ask questions like: What is the cost of keeping families separated at the end of life, and, if patient/ family centered care is so central to healthcare these days, why was it immediately discarded? Is potentially saving human lives worth the risk of damaging them beyond repair?
\end{abstract}

Keywords Covid-19 $\cdot$ Moral distress $\cdot$ Family centered care $\cdot$ Healthcare $\cdot$ Chaplain

When the editor of this special issue invited me to participate in this book, I was hesitant at first, unsure of where I would fit in. The editor asked me to think about a first person account of the humanity being saved and the humanity being lost. What do we lose when we alienate families? What does the patient lose? What is our moral responsibility to these patients and families? What does it cost our caregivers?

As the chaplain at a 600 bed, level 1 trauma hospital, I've seen a plethora of issues that stem from our visitation policy. When the pandemic started and the world shut down, it was simple—no visitors. It happened literally overnight: no visitors for adult patients. Children got one parent and that was it. The halls were eerily quiet; in an atmosphere normally so focused on family-centered care, how could we provide this standard without the family allowed to be here? As a chaplain, I spent time with patients of course, but I spent much more time with the staff who were reeling from the sudden new dangers associated with their jobs-dangers that meant sending their small children to stay with relatives or sleeping in their own pool houses. People were scared. The complexities of their home lives were suddenly directly impacted by their jobs. People work in healthcare because they care about people; they care for strangers. Now that care and passion could directly impact their families, the very families they work to support. More than once I sat with nurses crying

Rachel M. B. Greiner

rachelbutler@live.com

1 Savannah, GA, USA 
in stairwells, in break rooms, struggling to weigh their options: work here or stay home? Find another job? Send kids to stay with in-laws in the next town? At the same time, they care deeply for their patients and watching them die from a virus that we know so little about is exceedingly difficult. One nurse said to me, "Give me a gun shot wound any day. That I can do. That I understand. I can see that trajectory. This is just so defeating." Over time, job satisfaction seemed to plummet.

I also spent a lot of time on the phone with family members of patients. They were scared and while a few were more anxious than others, most understood the precautions; they were just as worried about themselves as they were about their hospitalized loved ones. Chaplains started using WebEx, a video conferencing application, to be able to show family members their loved one. Pastoral Care became WebEx Central in our hospital. There were some days I didn't do anything else. There needed to some connection between patients and families, even if it was only digitally.

It quickly became apparent that end-of-life situations merited something different. As a society, we aren't comfortable with people dying alone. There's even a national organization called No One Dies Alone (NODA) to be sure hospitals can train volunteers to sit with dying patients who would otherwise be alone. Our own hospital has such a program, but it is not designed for utilization in a pandemic. So our rules needed to change. For a while, a dying patient could have two visitors. Then a dying patient could have a rotation of visitors-immediate family-but it was a timed visit that had to be coordinated by pastoral care. I call the family spokesperson and get the list of names and relationships and set a time for them to visit. I gather all of them in the waiting room of the unit and escort them in, two at a time to the bedside where they were allowed to stay 10 or maybe 15 minutes depending on how many were on the list. When the visits finish I escort them out. Two people would be allowed to stay until the patient died. I should note, this is for non-Covid patients; people dying from coronavirus were not allowed any visitors for quite some time. Then the rule changed to allow for one visitor to stand outside the glass door and say goodbye from the hallway; that was a gut-wrenching scene. As case numbers rose, our rules changed and again and eventually, the standard rule became no visitor at all for Covid-19 deaths. Of course, with everything, there are some exceptions, which I'll discuss later.

Meanwhile, our policy for regular visitation changed as well: for a short time every patient could have two visitors, but then it went back down to only one... the running joke was that the visitation policy changed every day, making it nearly impossible to enforce the rules. Finally the powers that be landed on five. Five visitors, one time, for end of life. The process is very involved and everyone must be approved by a small team who looks at every case individually. Once everyone is approved, the visit must be coordinated by pastoral care so my department stays incredibly busy. Even at the time of this writing, this is the majority of a chaplain's work in our hospital.

Except instead of being chaplains, we end of being police. We're policing not only the families but the staff members who think they are "doing the right thing" or believe they "can get away with it" when they let a patient have overnight visitors, or they let six family members into the room at one time (which in fact makes it harder 
for families in the long run). How do we keep the public safe, keep our team safe, and do right by dying patients and their loved ones? Are we undermining our ability to provide excellent, well-rounded care by putting such restrictions on visitation?

The following stories attempt to illustrate some of the difficulties within such parameters. All patients, families, and staff members have been de-identified. I hope to show the reader the humanity behind the numbers associated with Covid-19. I'll also illustrate how this virus isn't just impacting those who have it, but everyone.

$* * * * *$

"So this is the last time I'll see my mom?"

His words hung, incredulous in the air. He knew the answer was yes. I knew the answer was yes. He needed to hear me say it. He needed to know definitively that his next thirty minutes would be the last he would ever spend with his mother. I'm a mother. I imagine her knowing his pain. Maybe she does. I hate this part.

"Yes sir."

He looked at me. I saw a flash of anger but it was quickly replaced with resign. We'd had lengthy conversations about this. He knew the rules; he knew why they existed and he'd agreed to them.

Mrs. W. had a husband, two adult children, several grandchildren, nieces, nephews, siblings, and friends. She was active in her church and she liked the garden. She'd fallen and hit her head while on blood thinners-a routine death sentence for people in their 80s. She didn't even have coronavirus, yet it would dictate her last hours.

Due to the virus, our visiting policy has changed several times. During Mrs. W.'s stay, she could have one designated visitor if and until she reached end of life. If she was deemed to have less than 72 hours to live, a "final visit" could be arranged for four additional visitors, bringing the number of people who could tell her goodbye to 5. After the final visit, two people could stay with her until she died. Mr. W. had been by her side since she arrived. Something about old men who are broken gets to me; those tears are some of the hardest to watch fall. Over the past few days, we'd had conversations about how they met in their teens and had been married 62 years. They were each other's first love. He'd hold her hand and tell me about their lives together. He'd shuffle in at 9am every day, the time that visitors were allowed. And he'd leave at 6 pm every night, to go home and sleep, only to be back the next day. When the time had come for hospice, he was sad, but understood. She would often open her eyes and occasionally she'd squeeze hands on command or look the direction she was asked, but not consistently and Mr. W. knew she didn't want to live like this.

We arranged for the two adult children and two grandchildren to be the additional four visitors. The grandchildren were adults too and they were the first ones in. They spent their thirty minutes, telling her they loved her, FaceTiming other relatives, kissing her cheeks, and finally saying goodbye. As I walked them back out to the waiting room, they cried the hard tears they didn't want her to witness. They stood briefly in the hallway between her room and the waiting room, holding each other and crying. I stood next to them, feeling their grief from the outside. They looked at me and said they were ready. They wiped their faces and straightened their postures as though they needed to be strong for their parents. As we entered the waiting room, 
they went first to Mr. W. and hugged him, assuring him that everything would be ok. They hugged their uncle and their mother, who stood and looked at me, expectantly.

"Are you ready to see her?"

They walked towards me and that's when her son asked me his question-the question that weighed so much not only for him but for me too: "So this is the last time I'll see my mom?"

As the three of us walked back to her room, we walked slowly, deliberately. He stopped, unbeknownst to him, in the same place where the grandchildren stopped. He seemed to need a minute. His sister stopped and walked back towards him a bit; she touched his shoulder. "Are you ok?" She asked.

"...no" and a sob escaped him. He hung his head, covered his face, and wrapped his arm around himself as if he were alone and scared. I couldn't help but see him as a little boy in that moment. So broken and lost. Looking back, I think of my own sons, the oldest one 4 years old; I imagine him one day having to say goodbye to me. I am hopeful he is surrounded by more than his own arm when the time comes.

His sister stood awkwardly for a moment and then she moved to hug him. He allowed it briefly and then broke away, looked at me, and nodded.

I nodded back and we resumed our trek. We made it to her room and pulled the door and curtain open so they could see her as they walked in. Having not seen her until now, they both balked, only for a second, to see her on a ventilator, looking so frail in the bed. They walked in, faking cheerfulness and cooing at her. $* * * * *$

Mr. L. was a husband, father, grandfather, uncle, and lover of the musical group Heart. He had coronavirus and was dying on our Covid ICU floor. Our visitor policy at that time was absolutely no visitors for anyone with Covid-19, so his family hadn't seen him in several weeks. He'd done ok in the beginning but had gotten worse and worse. Family is only allowed to call for updates between 10 and 2 and a doctor should theoretically call them once a day. Suffice to say, most loved ones were less than thrilled with the amount of communication from the hospital. For many families of Covid patients on ventilators at this hospital, chaplains serve as a major mode of communication.

We use WebEx, a video conferencing software that is installed on hospital iPads. I call the family ahead of time and instruct them how to download the application and then how to join the meeting when the time comes. Mr. L.'s family had "WebExed" with him early on but had been so jarred at seeing him intubated, they elected not to use this communication again. Instead, we used the call bell. I'd call them on my cell phone, hold its speaker up the intercom receiver, and Mr. L. could hear their voices in his room, if he could still hear... and I always assume that hearing is the last sense to go and encourage families to assume the same.

However, today we were going to extubate Mr. L. We'd turn off his pressers, remove the breathing tube, and the team was sure he would die quickly. The family wanted to see him. I was happy to do the WebEx for them, but realized that from the safety of the hallway where I usually conduct these meetings, Mr. L. would not be able to hear the voices of his family. I decided to be in the room during his extubation so the family could "be" there too. I found the scrub depot, got the extralarge scrubs that were left and hastily put them on. I tucked the bottoms of the pants 
into my shoe covers, cinched the waist as tightly as I could and tried to ignore the fact that I looked like a kid wearing my dad's oversized clothes. I put on the plastic gown, and piled my hair in a bun on the top of my head. It's easier to keep the N95 mask situated when your hair is up. I put on the plastic face shield, and the head cover. Lastly, I put on the gloves and dialed in the family. The only part of my entire body exposed to any part of the room was the back of my neck, and I'm fairly certain I can't catch Covid back there. Still, I was acutely aware of how the team must feel, wearing this for 12 hours a day.

The family didn't want to see the act of extubation so I left the camera flipped towards me and I described what the team was doing. When they finished, I flipped the camera towards Mr. L. and got closer. I held the iPad over his face and his family began to speak. They spoke of their immense love for him, of the things he had taught them; they spoke of the lives they would lead because of him. The six year old asked him to wake up. His sons called him 'sir' and promised to take care of their mother. His wife sobbed. She apologized profusely for not being in the room. She thanked him for loving her for all these years.

The conversation dwindled along with his heart rate. I asked the family if he had any music that he liked and that's when they all laughed and said anything by Heart would do. And that's how, after three songs, the smooth voice of Ann Wilson singing Alone carried Mr. L. to the Next Place.

His family was grateful that they had been afforded the opportunity. They thanked me profusely. I felt guilty accepting their thanks. I would've preferred them to be here in person as I know they so desperately wanted as well. I felt we did right by the patient in the circumstances; we gave him the best sendoff we could and that's the part I hang on to.

$* * * * *$

Mrs. B. was 83 and had Covid. She was on our Covid ICU floor and not allowed any visitors. I spoke with her daughter daily. I'd offered several times to do a virtual visit, but her daughter was adamant that she didn't want to see her mother like that. Instead, we used the intercom option. Every day, the daughter would call me and sometimes her sister would be with her, a few times her dad was with her, and they'd talk to Mrs. B. without seeing her. They'd vacillate between cheerleader: "We love you Mama! We're praying for you; you're so strong; you've got this!" and guilt trip: "Mama, you have to fight. You have to live. I cannot live in this world without you. You just keep fighting Mama; we don't care what the doctors say, you have to live!" I always felt uncomfortable with the latter-it seemed unfair to Mrs. B. in the bed. She continued to do worse and worse. The team was experiencing moral distress at all they were doing TO her instead of FOR her. The family was adamant that everything must be done. One day, I nearly begged her daughter to do the WebEx virtual visit. I thought surely if she could just see her mother-if she could see how bloated she was, how her skin was weeping - if she could see the sheer number of bags hanging and the dialysis machine and the ventilator and the cooling blanket and, and, and...but the daughter still refused.

Eventually, painfully, the family agreed to a DNR. This poor woman had coded multiple times and her pulse kept coming back again and again. The daughter 
texted me the next day to say that her mother's best friend would be calling to speak on the intercom to Mrs. B. We agreed and scheduled a time.

G. was Mrs. B's best friend; they met when they were six months old. They'd been inseparable ever since- 82 years and 9 months she told me. They'd been in each other's weddings, at the births of their children, and at the funerals of their parents. They still lived in the same small town where they'd been born. "I love her like no one else in my life," G. said. "Like sisters who share a heart but not blood."

After sharing a few more stories of their younger days and the shenanigans they'd gotten into, I put the speaker up to the intercom receiver and told her she was on with Mrs. B.

"E? This is G. Honey, you go on and go. Everything's fine here. I'll take care of your babies. Jesus is waiting on you. You go on and I'll see you soon. I love you."

After we hung up, I walked back towards Mrs. B.'s room where a small crowd was gathering. Her heart had stopped. In the time it took me to walk the thirty yards from the nursing station to her room, she died. Her best friend told her it was ok to go and she did. G. loved her that much. I teared up and the team thought I was crying because Mrs. B. was dead. But I told them what had just happened and we all stood there, tears brimming and spilling into our masks. We cried tears of joy for Mrs. B. who was finally free of Covid-19 and all it brought with it. We cried that we were free from torturing her. We cried that her children were free from the back and forth roller coaster of ICU care and decisions. We cried and our masks got wet. We cried and a little bit of the weight of that case lifted.

$* * * * *$

Ms. S. was 34. She'd just had a baby at an outside hospital; the baby was born at 30 weeks and transferred to our neonatal unit. Ms. S. had Covid-19. The day after she delivered her daughter, she coded and was transferred to our hospital where she sat in our ICU for weeks. Her daughter was doing well in the NICU. And for a while, Ms. S. was doing well. She didn't open her eyes, but she did follow some commands; she'd squeeze your hand, she'd move her foot...it seemed she was in there and aware of us out here. The team taped pictures of her baby to the wall in case she did open her eyes. They gave her daily reports about her daughter. We tried to make sure she'd have a Spanish speaking nurse so she could understand those updates, as her chart indicated she only spoke Spanish. Her sister-in-law called for updates daily and would share with the nurses how the baby was doing. The family was so anxious to have both the baby and Ms. S. home.

And for as well as she'd been doing, it was quite a shock to the entire team when she "crumped"- the word officially used to describe patients when they decline so rapidly seemingly out of nowhere. I was notified that Ms. S. officially met criteria for our EOL list-end of life list. This is a list for patients expected to die in 72 hours or less. Pastoral care can set up a one-time visitation for them and up to five family members. Unless the patient has Covid. Then she can only have one visitor and it has to be specially approved by the physician, by nursing, and lastly by administration. As the chaplain, I'm merely the one to contact the family and let them know if one person can come or not. In this case, Ms. S. could have one visitor and it was to be her mother. 
Mrs. S. was a very small woman; I met her in the front lobby of the main hospital and we had to walk to the other side of campus, where the ICUs are located. Usually on this long walk with families, we spend the first two hundred steps talking about how big the place is, how they'd get lost without an escort, and how much we all hate this virus. It's a bustling part of the hospital so real conversation is difficult. But midway is quieter and I usually ask about the loved one we're going to see; I hear stories of what they were doing right before getting sick, I catch glimpses of the personality that I'll never meet, and I start to see what the relationship was like between the patient and the family I'm escorting in to say a final goodbye. And by the last leg of our journey, we're often already into the anxiety and grief, and the explanation of what will happen next. They get 30 minutes, two at a time in the room, and then I escort them out so the next two can come in. Of course, none of this matters to Mrs. S. because she has to do this visit alone... with a chaplain who doesn't speak her language. I offered my broken Spanish introduction and condolences for what was about to take place. She offered her broken English acceptance and gratefulness for being here. And then we made that long walk in silence. It was particularly busy in one hallway and at one point, she clutched my arm. I rested my other hand on hers and we walked like that, silently to the room where her daughter lay dying.

When we arrived, we began putting on all of the proper PPE. I called the interpreter but she was with another family and we were next on her list. I don't know how to instruct donning PPE in Spanish and neither did the nurse, so we dressed her ourselves. She allowed it and it seemed she was using that time to put on her mental armor as well. One thing I know for certain in this life-there is nothing harder than the death of a child. Their age matters not. This mother was gowning up for what would likely be the hardest experience of her life-a fact not lost on her or us, the duo clothing her in PPE.

We entered the room and Mrs. S. began crying. Pictures of her grandbaby were taped to the wall all around her beautiful daughter who barely looked like herself after three weeks in the ICU. She rushed to her daughter's side, clutched her hand, and dug out a rosary from her purse. She began praying. The rooms are so loud, and she was wearing an N95 plus a face shield, so even if I could speak Spanish, it would've been nearly impossible to make out what she was saying. It turns out grief is its own language. I called the priest who also speaks Spanish; I put him on speaker phone and he prayed with us for which Mrs. S. was grateful. Then we stood there, she and I, along with two nurses and eventually the physician who joined us just in time for Ms. S.'s death. Her mother was confused because the machine was still ventilating the patient, but the doctor explained that her heart stopped. It wasn't until the respiratory therapist came in and turned off the machine that it really hit Mrs. S. Even though the doctor spoke Spanish fluently and Mrs. S. could understand every word, it took seeing her daughter's chest still to really understand she was gone. She laid across that still chest. She sobbed and covered her daughter's face with kisses. She took off her shield and face mask in order to do so and none of us stopped her.

The interpreter and I walked Mrs. S. downstairs and to the entrance where we waited with her for her family to come pick her up. She was mostly quiet, shocked at what had just transpired. When she did speak it was to say thank you. She thanked 
us profusely. For what? I wondered. For not being able to save your daughter? For keeping your family away from her while she was dying? For not being able to at least communicate with you more proficiently? My own grief at so many deaths was overwhelming, but this was her grief so all I could say was, "You're welcome...de nada...I wish we could've done more..."

******

“... and so I'm sorry to tell you Mr. C., but your wife died."

I was sweating already. It's one thing to wear full PPE inside where they keep the building 65 degrees all year, but it's a whole different ball of wax wearing in outside in the summer midday sun. I looked around. How did we get here? This feels so wrong.

Mrs. C. hadn't felt well that morning and her husband called EMS when he noticed a mental status change. By the time she got to our ER she was in full arrest and despite our best efforts, she died. We learned shortly after her death that she had Covid-19. Since she had the virus, she could not have a visitor, even in death. Unfortunately, her husband had the virus as well and as such he wasn't even allowed in the building. He was sitting in the parking lot of our ER in the hot South Georgia sun, trying to be socially distanced from the small groups out there, also waiting to be allowed to see their loved ones.

We were standing between the dumpster and the side of building; it seemed to offer at least some privacy and a sliver of shade. What a horrible place to receive the worst news of your life. Mr. C. was looking at us, dumbfounded, when his phone rang. He glanced down at it and to my surprise, he answered it. "It's the hospital," he mumbled. Dr. T and I looked at each other. Why in the world was the hospital calling him right now?!

Mr. C. made some general acknowledgment sounds and then said, "Thank you Dr. L" and he hung up.

“Dr. L?” I said. Dr. L was one of our intensivists. Mrs. C. didn't even make it to him. Why in the world was he calling?

"My son's doctor. He's here too... with the Covid...he's not doing too well I guess..."

We three stood there for a moment, letting the gravity sink in. This man's wife had died and his son was potentially dying of the same virus. Dr. T offered condolences again and excused himself, leaving Mr. C. and me standing and sweating in the parking lot of the emergency room.

"Mr. C., I'm so sorry." There it is again, that tired old phrase that is just so meaningless. I'm so tired of being so sorry.

"Thanks for all you did...what do you need from me now?"

"I'm more concerned with what I can do for you... do you want me to find you a chair...or something?" This was totally against my training, looking for an escape, but the man was reeling and now leaning on a dumpster...I was afraid he might collapse.

"No, no...do you pick a funeral home, or what happens now?"

"Well, no sir, you pick it and let me know. We call them and they call you and walk you through some next steps. But we're in no hurry. You can talk to your family about it and call me later today if you need to..." 
"What family?" His tone was sharp. I stood quietly. He wiped sweat from his forehead. "I'm sorry. I've got to go. I might postpone this thing if my son needs a funeral too." He started walking away from me, quickly and determined. "I'll just have one double funeral instead of two," he half shouted at me over his shoulder.

I didn't go after him. There was nothing else to say, nowhere to take him. I stood for a moment, making sure he wasn't going to come back. I watched him start his truck and drive away.

"Pick up the phone and dial for a code blue!"

I've seen hundreds of code blues in my tenure as a chaplain, but I'd never been asked to make the phone call. This unit didn't have the buttons on the wall so I did as I was told and watched as people began streaming in. There was a bottleneck in the hallway though because the patient was Covid positive and full PPE must be donned before entering the room, even during a code.

Mr. W. had just been on the phone with his wife. I would learn later that he'd gone to church on Sunday-their first Sunday back to worshiping in person. He and his wife had a lovely time but by Tuesday, they both felt terribly. They were tested and both came back positive for coronavirus. By Wednesday night of the following week, Mr. W. had his wife, who was faring far better symptomatically, bring him to our ER. Thursday morning he was doing better, but needed highflow oxygen and here we were, Friday morning, coding a man in his late fifties who'd hung up with his wife not ten minutes ago.

The social worker had the Mrs. W. on the phone and was giving her a play-byplay of the code. It lasted over twenty minutes. Finally, the attending in the room, sweaty and out of options, asked if anybody had any more ideas. No one did. The code ended and the patient's time of death was called-0818.

Dr. E. took the phone from the social worker and delivered the news to Mrs. W. who was shocked. By the time I got to call her and offer condolences, she was still spinning. "How could this happen?? I JUST talked to him!!" At one point she asked me to double check his wrist band to make sure I had the right wife on the phone. As her shock ebbed, we talked about their lives together and the family they'd raised. I inquired as to her health and she said her virus had been fairly mild with fatigue being the worst part. At one point, I said, "I'm so sorry you're alone right now; I wish things were different."

"Oh, I'm going to my mother's house," she said. I could hear background noise as she was readying to leave the house. I was shocked to hear her plan. My silence gave me away.

"You don't think I should go?" she asked.

"How old is your mother?" I asked quietly.

"Eighty-six...Do you think this is a death sentence for me too?" her voice gave away her anxiety.

"No, but I think it likely is a death sentence for your 86 year old mother..." I said this quietly, stunned by my own candor. My job relies on helping folks find their own wise counsel, not offering mine.

After a few minutes she sniffled and said, "I just don't want to be alone right now!" 
"I understand. But you also don't want to bury your mother and your husband in the same month." I felt my own disbelief rising. Her husband literally just died from this-does she not understand? She got it from church where she wore a mask and everything! Can't she see how easily this is spread?!

She eventually agreed not to leave and asked if her mother could come to her house. I have to assume her grief and shock was clouding her judgment and I walked her through why that wasn't a good idea either. We talked about FaceTiming her children, about calling her mother, and about how important it would be for her to continue to quarantine, even now. We hung up with that plan in place, but I'd bet my last N95 that she went anyway.

******

Ms. J. was 30 years old and dying from Covid. Her mother, Mrs. K., was on the step-down floor above her, recovering from Covid. Her sister, also Ms. J., had just been released yesterday, having battled the virus successfully enough to return home.

This Ms. J. would not be so lucky. Her doctor called me and explained that the patient's mother was in the room almost directly over Ms. J.'s and how hard did I think it would be to arrange a visit. That is how it came to pass that coronavirus was both blessing and curse-curse that it killed her daughter, but a blessing that it allowed this mother to be with her daughter while she died.

Mrs. K. was wailing when I met her. The doctor had just told her that her daughter would not survive. She begged me to say it wasn't true. She begged me to tell her it was a joke. She wept and clung to my hand while I explained we'd made some arrangements to allow her to visit Erica.

Unbeknownst to Mrs. K., four people in the C-suite had the final say about who would be with her daughter while she died. And after Ms. J's nurse and nurse manager agreed, and Mrs. K.'s nurse and nurse manager agreed, and both physicians agreed, the chief nursing officers, the VP of Ethics, and the director of accreditation said yes. To their credit, it happened fairly quickly, not like the slow moving beast that healthcare can often be.

Mrs. K. was understandably devastated, but she kept clinging to hope that God would give her daughter a miracle. Her family was FaceTiming her from outside the hospital. I recognized the front circle, the main fountain, and the trees from various parts of our campus. They were all here, yet unable to be with their beloved sister, cousin, daughter, and granddaughter. They tearfully took turns calling in and saying goodbye. They often prayed. One sister prayed for nearly 40 full minutes. Mrs. K. stared at Ms. J, sometimes touching her face and asking her to please wake up.

My phone rang in my pocket. I quickly silenced without checking to see who it was. It wasn't my hospital cell phone, but my personal one; I would check it later. The next family member called and there was more prayer, more tears. I could tell Mrs. K. was worn out. She no longer went through the entire saga of Ms. J's journey with each new call. She was resigned and merely held the phone up so they could view Erica's face, puffy and swollen, hair a mess, mouth pried open with a piece of plastic tubing that was keeping her alive-as close to alive as she could be. Mrs. K. was sick too, I had to remind myself. Likely she was exhausted. We'd been down here over an hour by this point. 
My phone rang again. This time I glanced at it. Daycare. A few quick button pushes revealed that was the call I missed a few minutes ago as well. Which meant they called my husband when I didn't answer, and he hadn't answered either so they were calling be again. Reluctantly, I stepped out of the room.

"Rachel, this is Ms. T. Your son's teacher tested positive for Covid so he's been exposed and you have to come get him and his brother right away. You have to pick them up within 30 minutes. We tried calling your husband but we couldn't get him..."

I closed my eyes. I'm fairly certain I rolled them as well. The teacher hadn't been in the center all week; likely my children were not "exposed". She'd said it like it was a death sentence. I gathered myself to step back into the room and noticed how acutely aware I was of the gravity of this illness, while simultaneously rolling my eyes at its extreme inconvenience.

Mrs. K. was reluctant to go, but her daughter would hang on several more hours. In fact, another chaplain would be called to escort Mrs. K. down one last time, just in time to see Ms. J. succumb to this awful virus. And from there, she herself was discharged and Chaplain $\mathrm{M}$ walked with her to the front door where thirty of her family members were waiting to embrace her... and her coronavirus. She didn't quite understand that just because she was well enough to go home didn't mean she didn't have to quarantine. Grief, in a time of coronavirus, overwhelms common sense. That's not a judgement, it's merely a fact. Time and again, all over the country, people make bad decisions in the name of grief. Going to funerals, seeing aging parents after months apart, needing connection, etc. And who can say when risk outweighs burden, but the carrier of both?

While this virus is brutal in its selection of who will live and who will die, it seems the healthcare system has mimicked its brutality in keeping families separated during this awful time. Families have asked me why I can go in the room, why nurses and doctors can go in the room but they cannot. Why should we be afforded PPE while they are not even allowed in the building? One family cussed me up one side and down the other while exclaiming that this was their worst stay in our hospital ever. The wife of the patient screamed at me, red in the face, spit flying from her (unmasked) mouth while she demanded to know how I slept at night. And while I know it really has nothing to do with me, I didn't tell her that I often don't sleep so well these days.

They say necessity breeds creativity and that's what we've done: we've gotten creative with the way we include families in the care of our patients. It's creative but it isn't good enough-especially at end of life.

$* * * * *$

A 3 year old drowned. Drowning are the worst for me. You can't rationalize it by saying to yourself, well this is why I don't keep guns in my house, or, she shouldn't have been driving drunk. There's no one to blame when it comes to drowning. It happens so fast and it can happen to anyone. More than once I've been at the beach with my children only to panic for fifteen seconds while scanning for my two year old. He's always been right there, but fifteen seconds is all it really takes.

This 3 year old was a little girl who had two loving parents, an older brother, two sets of grandparents, several aunts and uncles, cousins, daycare providers, and a godmother who loved her like her own. The parents had been there round the clock but 
when $\mathrm{S}$. was pronounced brain dead, only her maternal grandparents and brother were allowed as the extra visitors. I could talk about her mother singing "This Little Light of Mine" to her or her eight year old brother reading a letter that he wrote to her, begging for her forgiveness, but for now, I'll stick with the moral distress of the team. Our Pediatric ICU is small; when a tragedy like this happens, every single patient and family member present knows it. Every nurse is impacted. Every respiratory therapist, every pharmacist, every resident and medical student: we all walk with a somber grimace on our faces. The environmental services people can be seen weeping in the corner, the cafeteria people delivering food trays are quiet, their usual chatter quieted for the week. The bedside nurse took me aside, tears in her eyes and asked me to let the pastor in, to let the paternal grandparents in, to let the godmother in. They were all calling and while they couldn't get any information, they were just crying and begging to be let in. We used the iPad, we WebExed with anyone who wanted to. It wasn't the same.

After S. was declared brain dead and her family left for the day, I walked her parents out the front door of the building. No less than fifty people were standing outside, waiting to envelop that mom and dad. The mother saw them all waiting for her and she stopped walking. Her knees buckled and she would've hit the pavement but for the swell of this gathering rushing to catch her. Her soul broke open and the wail that only comes from a parent this broken escaped her body. It brought every hair on my head and arms to attention. It was sharp and piercing. Her husband could offer no support because he needed his own. The group split organically, men hugging and helping Dad, while the women laid Mom down on the ground, joined her there, and wept together. If not for the excruciating pain of watching such an event, it would've been an interesting study of humanity and how we care for one another. This group of fifty people knew they could not see S.; they knew they wouldn't be allowed inside and yet they came anyway. They stood for days outside, coming and going, bringing each other food, holding vigil for this family. It was 101 degrees that day; they still showed up. One family member was taken to the ER for passing out in the heat, but everyone else stayed. Even after S. was gone, this group stayed for another two hours, loving this family beyond the heat, beyond the restrictions.

Do I think S's family would've benefited from lesser restrictions? Maybe. They certainly would've been more comfortable, if only physically. But I do think the team would've fared better. S. was number 3 in a string of multiple pediatric drownings this summer; this case still stings those that cared for her.

For those who've lost loved ones from the virus or anything else during this time, their losses will always be tainted. It wasn't what they pictured when they thought of saying goodbye to their mother or grandmother, to their brother or uncle. It certainly wasn't how they should say goodbye to their children. This virus has taken so much from us already and now it's taking away from our community as we strive to learn to grieve alone. I'm not sure there is a better answer, but I think the question is worth asking: Does the potential benefit outweigh the risk?

Publisher's Note Springer Nature remains neutral with regard to jurisdictional claims in published maps and institutional affiliations. 